Article

\title{
Interaction between Dietary Fat Intake and Metabolic Genetic Risk Score on 25-Hydroxyvitamin D Concentrations in a Turkish Adult Population
}

\author{
Kubra Isgin-Atici ${ }^{1,2,+}(\mathbb{D})$, Buthaina E. Alathari ${ }^{3,4,+}{ }^{,}$Busra Turan-Demirci ${ }^{1}$ (D), Suleyman Nahit Sendur ${ }^{5}$, \\ Incilay Lay ${ }^{6,7}\left(\mathbb{D}\right.$, Basma Ellahi ${ }^{8}$, Mehmet Alikasifoglu ${ }^{9,10}$, Tomris Erbas ${ }^{5} \mathbb{D}_{\text {, Zehra Buyuktuncer }}{ }^{1, *,+}$ \\ and Karani Santhanakrishnan Vimaleswaran $3,11, *++_{(\mathbb{D}}$
}

check for

updates

Citation: Isgin-Atici, K.; Alathari, B.E.; Turan-Demirci, B.; Sendur, S.N.; Lay, I.; Ellahi, B.; Alikasifoglu, M.; Erbas, T.; Buyuktuncer, Z.;

Vimaleswaran, K.S. Interaction between Dietary Fat Intake and Metabolic Genetic Risk Score on 25-Hydroxyvitamin D Concentrations in a Turkish Adult Population. Nutrients 2022, 14, 382. https://doi.org/10.3390/ nu14020382

Academic Editors: Giovanni Passeri, Sandro Giannini and Carsten Carlberg

Received: 10 October 2021 Accepted: 14 January 2022 Published: 17 January 2022

Publisher's Note: MDPI stays neutral with regard to jurisdictional claims in published maps and institutional affiliations.

Copyright: (C) 2022 by the authors. Licensee MDPI, Basel, Switzerland. This article is an open access article distributed under the terms and conditions of the Creative Commons Attribution (CC BY) license (https:// creativecommons.org/licenses/by/ $4.0 /)$.
1 Department of Nutrition and Dietetics, Faculty of Health Sciences, Hacettepe University, Ankara 06230, Turkey; k.isginatici@gmail.com (K.I.-A.); busraturan@hacettepe.edu.tr (B.T.-D.)

2 Department of Nutrition and Dietetics, Faculty of Health Sciences, Amasya University, Amasya 05000, Turkey

3 Hugh Sinclair Unit of Human Nutrition, Department of Food and Nutritional Sciences, University of Reading, Reading RG6 6DZ, UK; b.e.a.a.alathari@pgr.reading.ac.uk

4 Department of Food Science and Nutrition, Faculty of Health Sciences, The Public Authority for Applied Education and Training, AlFaiha 72853, Kuwait

5 Department of Endocrinology and Metabolism, School of Medicine, Hacettepe University, Ankara 06230, Turkey; snahitsendur@hotmail.com (S.N.S.); erbast@hacettepe.edu.tr (T.E.)

6 Department of Medical Biochemistry, Faculty of Medicine, Hacettepe University, Ankara 06230, Turkey; lincilay@gmail.com

7 Clinical Pathology Laboratory, Hacettepe University Hospitals, Ankara 06230, Turkey

8 Faculty of Health and Social Care, University of Chester, Chester CH1 4DS, UK; b.ellahi@chester.ac.uk

9 Department of Medical Genetics, School of Medicine, Hacettepe University, Ankara 06230, Turkey; kasif@hacettepe.edu.tr

10 Genetics Diagnostic Centre, DAMAGEN, Ankara 06230, Turkey

11 Institute for Food, Nutrition, and Health, University of Reading, Reading RG6 6AH, UK

* Correspondence: zbtuncer@hacettepe.edu.tr (Z.B.); v.karani@reading.ac.uk (K.S.V.); Tel.: +90-312-305-1094 (Z.B.); +44-0118-378-8702 (K.S.V.)

+ These authors contributed equally to this work.

\begin{abstract}
Previous studies have pointed out a link between vitamin D status and metabolic traits, however, consistent evidence has not been provided yet. This cross-sectional study has used a nutrigenetic approach to investigate the interaction between metabolic-genetic risk score (GRS) and dietary intake on serum 25-hydroxyvitamin D [25(OH)D] concentrations in 396 unrelated Turkish adults, aged $24-50$ years. Serum 25(OH)D concentration was significantly lower in those with a metabolicGRS $\geq 1$ risk allele than those with a metabolic-GRS $<1$ risk allele $(p=0.020)$. A significant interaction between metabolic-GRS and dietary fat intake (energy \%) on serum 25(OH)D levels was identified $\left(P_{\text {interaction }}=0.040\right)$. Participants carrying a metabolic-GRS $\geq 1$ risk allele and consuming a high fat $\operatorname{diet}(\geq 38 \%$ of energy $=122.3 \pm 52.51 \mathrm{~g} /$ day) had significantly lower serum $25(\mathrm{OH}) \mathrm{D}$ concentration $(p=0.006)$ in comparison to those consuming a low-fat diet $(<38 \%$ of energy $=82.5 \pm 37.36 \mathrm{~g} / \mathrm{d})$. In conclusion, our study suggests a novel interaction between metabolic-GRS and dietary fat intake on serum $25(\mathrm{OH}) \mathrm{D}$ level, which emphasises that following the current dietary fat intake recommendation ( $<35 \%$ total fat) could be important in reducing the prevalence of vitamin $\mathrm{D}$ deficiency in this Turkish population. Nevertheless, further larger studies are needed to verify this interaction, before implementing personalized dietary recommendations for the maintenance of optimal vitamin D status.
\end{abstract}

Keywords: vitamin D; TCF7L2; MC4R; genetic risk score; fat intake; metabolic traits 


\section{Introduction}

Nearly one billion people suffer from vitamin D deficiency (VDD) globally [1]. The prevalence of VDD among adults has been reported as $~ 40 \%$ in Europe [2] and 44-96\% in Asia, the Middle East, North Africa, and 30-90\% in West Asia [3-7]. Despite having high levels of sun exposure, VDD remains a significant problem in Turkey [8,9]. A meta-analysis of data from 111,582 Turkish participants reported that the prevalence of VDD was 63.5\% (58.9-66.6\%) in adults, $76 \%$ in pregnant women, $39.8 \%$ in children, and $86.6 \%$ in infants [8]. In addition to the genetic determinants of vitamin D status, personal characteristics such as age, gender, skin colour, race, religious beliefs and clothing style, and lifestyle factors including physical activity level have been suggested as potential factors that can affect the levels of vitamin D in the Turkish population [8,10,11].

As a member of secosteroid hormones, vitamin D plays essential roles in both calcium and phosphorus metabolism, cell proliferation and differentiation, muscle contraction, nerve transmission, and function of the immune system [12]. Due to the immunomodulatory, anti-inflammatory, antifibrotic, and antioxidant roles of vitamin D, its deficiency has associations with several diseases including obesity, diabetes, cardiovascular diseases, bone metabolic disorders, cancers, neuropsychiatric disorders and autoimmune diseases, and more recently with increased risk of SARS-CoV-2 infection [12-14]. The link between VDD and the risk of cardiometabolic diseases has been extensively studied [15-17], and it has been shown that vitamin D exhibits anti-adipogenic activity in 3T3-L1 preadipocytes [18,19] and has potential roles in inducing the expression of the insulin receptor, in the regulation of insulin secretion, glucose homoeostasis, and inflammation [20,21].

Despite the current evidence for the link between VDD and cardiometabolic diseases, a causal effect has not been established [22]. Furthermore, previous studies investigating this link are inconsistent due to the unmeasured confounding factors [23,24]. A genetic approach may provide a better understanding to the potential association between VDD and metabolic diseases by eliminating any unclear confounding factors [25]. The heritability of circulating vitamin D levels has been reported between $20-85 \%$, and a number of genetic variants in genes for vitamin $\mathrm{D}$ pathways have been associated with metabolic diseases [12,26]. Furthermore, several genetic variants associated with cardiometabolic health have also been linked to one's vitamin D level status. Melanocortin 4 Receptor $(M C 4 R)$ and Transcription Factor 7-Like 2 (TCF7L2) genes are commonly studied candidate genes for obesity and diabetes [25,27-39], and the interactions of MC4R and TCF7L2 genotypes with dietary intakes on obesity $[35,36]$ and diabetes related traits $[25,30,37]$ have been investigated in multiple ethnic groups. However, to our knowledge, the potential effects of the interaction between metabolic-genetic risk score (GRS) and dietary intake on vitamin $D$ status have not been investigated in a Turkish population. Hence, in the present study, we have explored the association of the metabolic-GRS with metabolic traits and vitamin $\mathrm{D}$ status and explored the interaction between metabolic-GRS and dietary intake on the vitamin D status of a Turkish population.

\section{Materials and Methods}

\subsection{Study Population}

This cross-sectional study was performed with 396 Turkish adults, aged 24-50 years. The study participants were enrolled following a physical examination by the research endocrinologists at the outpatient clinic of the Department of Endocrinology and Metabolism at the Hacettepe University Hospitals between June and November 2017. Criteria for inclusion required a routine visit to the outpatient clinic, being 24-50 years old, and with a Body Mass Index (BMI) of $\geq 18.50 \mathrm{~kg} / \mathrm{m}^{2}$. Those who had diagnosed liver and kidney diseases, mental and psychological disorders, cancers and severe endocrine abnormalities (hypothyroidism, hyperthyroidism, hypopituitarism, etc.), as well as those who were pregnant or breastfeeding, using drugs or dietary supplements that affect body weight, or have a history of bariatric surgery were excluded from the study. Following physical examination, all participants underwent a nutritional assessment and biochemical and 
genetic analysis. The study was approved by the Non-interventional Clinical Research Ethics Board of Hacettepe University (GO 15/612-11) in compliance with the Declaration of Helsinki, and written informed confirmation was obtained from all the participants. The details of the study, including the procedure for taking blood samples and transport to the laboratory have been previously published [40]. The study was performed as a part of the GeNuIne (Gene-Nutrient Interactions) Collaboration [41,42].

\subsection{Anthropometrical Measurements}

Height and body weight were assessed using standardised methods with a digital scale (Seca 220 Scale). BMI was calculated with the formula: "Body weight (in kilograms) divided by the square of height (in meters)" [43]. Waist circumference (WC) and hip circumference (HC) were measured by standard methods, and the waist-to-hip ratio was calculated by dividing WC $(\mathrm{cm})$ to $\mathrm{HC}(\mathrm{cm})$ [44]. Body composition was determined by bioelectrical impedance (Tanita MC- 980 MA). Fat mass index (FMI) was estimated as fat mass $(\mathrm{kg}) /$ height squared $\left(\mathrm{m}^{2}\right)[45]$.

\subsection{Biochemical and Clinical Measures}

Fasting lipid profile including triglyceride, total cholesterol, high-density lipoprotein cholesterol (HDL-cholesterol), low-density lipoprotein cholesterol (LDL-cholesterol), and both fasting and postprandial plasma glucose and insulin concentrations were analysed by routine methods at Hacettepe University (Biochemistry Laboratory). Plasma adiponectin and serum 25(OH)D concentrations were analysed in Hacettepe University (Clinical Pathology Laboratory) using ELISA kits (Ebioscience, Austria and Dia Source, Belgium, respectively). According to the Institute of Medicine's recommendation (IOM) [46], $\geq 20 \mathrm{ng} / \mathrm{mL}$ was considered as an optimal concentration for serum $25(\mathrm{OH}) \mathrm{D}$ concentration. Insulin resistance (HOMA-IR) was calculated using the formula: 'Fasting insulin level ( $\mu \mathrm{U}$ /L) x fasting glucose level (nmol/L)/22.5 [47]. Systolic (SBP) and Diastolic (DBP) blood pressure was measured as a part of the physical examination [48].

\subsection{Dietary Assessment}

Two trained research dietitians assessed the dietary intake using the 24-h-dietary recall method. The amount of food items consumed by the participants were confirmed using the food portion size photographic atlas [49], replicas of food items, and household measurement tools. Dietary energy and nutrient intakes were estimated using a dietary analysis computer program (BeBIS, Nutrition Information System, Version 8).

\subsection{Assessment of Physical Activity Level}

A Turkish version of the International Physical Activity Questionnaire (IPAQ) was used to determine the physical activity level of the participants [50]. The physical activity level was categorised into three groups based on Metabolic Equivalent of Task (MET) values suggested by the IPAQ protocol: sedentary $(<600 \mathrm{MET} / \mathrm{min} / \mathrm{w})$, moderate $(600$ $3000 \mathrm{MET} / \mathrm{min} / \mathrm{w})$, and vigorous (>3000 $\mathrm{MET} / \mathrm{min} / \mathrm{w}$ ) [51].

\subsection{Single Nucleotide Polymorphism (SNP) Selection and Genotyping}

SNPs, TCF7L2 rs7903146, and MC4R rs571312, were selected because of their associations with metabolic diseases that have been suggested previously in different populations [25,27-39]. The genomic DNA was isolated from the whole blood in K2EDTA containing tubes by the salting-out method. The details of this method have been described previously [40]. The genotypes of the TCF7L2 rs7903146 and MC4R rs571312 SNPs were in the Hardy-Weinberg equilibrium ( $p=0.101$ and $p=0.176$, respectively). Genotype distributions and MAFs for the SNPs of TCF7L2 and MC4R are given in Table S1. 


\subsection{Statistical Analysis}

The statistical analysis was performed with Statistical Package for the Social Sciences (SPSS) software (version 24). Descriptive data for continuous variables were given as the mean and standard deviation, and groups were compared using the independent sample $t$ test. Allele and genotype frequencies of two SNPs were computed by gene counting, and the chi-squared test was used to calculate the percentages of alleles/genotypes. The SNPs of TCF7L2 rs7903146 and MC4R rs571312 were used to create the GRS. A value varying from zero to two was given to each SNP, indicating the number of metabolic disease-associated risk alleles. The GRS was determined via the addition of the number of risk alleles through each SNP. The median value (1 risk allele) was used to classify the participants into two groups: Those with $<1$ risk allele and $\geq 1$ risk allele. The association analysis between the GRS and categorical and continuous variables was performed using logistic regression and general linear models, respectively. Logistic and linear regression analyses were performed to examine the interaction between lifestyle factors and SNPs. The models were adjusted for age, gender, obesity status, energy intake, and months of measurement, wherever appropriate. The variable 'month of measurement' was created based on the months (June-November) in which the participants were enrolled in the study. The participants included in June, July, and August were coded as 'Summer' ( $n=192$ for this group) while the participants included in September, October, and November were coded as 'Autumn' ( $n=204$ for this group). $p$ value $<0.05$ was considered to be statistically significant. The dietary factors and metabolic traits were assessed according to the vitamin D status classified by the IOM recommendation [46]. A power calculation was not conducted given that there are no available effect sizes from studies focusing on metabolic GRS and vitamin D levels in the Turkish population.

\section{Results}

\subsection{Characteristics of the Study Participants}

The mean of serum $25(\mathrm{OH}) \mathrm{D}$ concentration was $24.6 \pm 1.66 \mathrm{ng} / \mathrm{mL}$ in the study population, and the prevalence of VDD was $25 \%$ (Table 1 ). The general characteristics of the study participants including anthropometric measurements, biochemical parameters, dietary intake, and physical activity level are given in Table 1 stratified based on serum vitamin D levels (deficient/insufficient $<20 \mathrm{ng} / \mathrm{mL}$ and optimal $\geq 20 \mathrm{ng} / \mathrm{mL}$ ). No significant difference in clinical, anthropometric, and biochemical parameters was obtained between the groups ( $p>0.05$, for each).

Table 1. Basic characteristics of the study participants according to serum vitamin D levels.

\begin{tabular}{|c|c|c|c|}
\hline & \multicolumn{2}{|c|}{ Serum 25(OH)D Concentration * } & \multirow[b]{2}{*}{$p$ Value } \\
\hline & $\begin{array}{l}\text { Deficient/Insufficient } \\
\qquad(n=182)\end{array}$ & $\begin{array}{l}\text { Optimal } \\
(n=214)\end{array}$ & \\
\hline \multicolumn{4}{|l|}{ Anthropometric measurements } \\
\hline Body mass index $\left(\mathrm{kg} / \mathrm{m}^{2}\right)$ & $25.7 \pm 4.21$ & $25.8 \pm 4.11$ & $0.271^{\mathrm{a}}$ \\
\hline Waist circumference $(\mathrm{cm})$ & $87.0 \pm 10.79$ & $88.8 \pm 12.04$ & $0.938^{a}$ \\
\hline Hip circumference (cm) & $101.7 \pm 8.27$ & $101.8 \pm 7.41$ & $0.127^{\mathrm{a}}$ \\
\hline Waist-to-hip ratio & $0.86 \pm 0.09$ & $0.87 \pm 0.08$ & $0.404^{\mathrm{a}}$ \\
\hline Fat mass index & $6.84 \pm 2.96$ & $6.94 \pm 2.85$ & $0.559^{\mathrm{a}}$ \\
\hline Body fat mass (\%) & $25.7 \pm 7.90$ & $26.0 \pm 7.29$ & $0.890^{\mathrm{a}}$ \\
\hline Body fat mass (kg) & $19.1 \pm 7.55$ & $19.6 \pm 7.48$ & $0.556^{\mathrm{a}}$ \\
\hline Visceral fat percentage & $5.59 \pm 3.15$ & $5.89 \pm 3.25$ & $0.628^{a}$ \\
\hline \multicolumn{4}{|l|}{ Biochemical parameters } \\
\hline Glucose $(\mathrm{mg} / \mathrm{dL})$ & $88.1 \pm 8.21$ & $87.5 \pm 8.48$ & $0.305^{\mathrm{a}}$ \\
\hline Insulin $(\mu \mathrm{IU} / \mathrm{mL})$ & $8.1 \pm 0.39$ & $7.3 \pm 0.29$ & $0.055^{\mathrm{a}}$ \\
\hline Postprandial glucose (mg/dL) & $84.9 \pm 17.21$ & $84.7 \pm 15.72$ & $0.408^{a}$ \\
\hline Postprandial insulin $(\mu \mathrm{IU} / \mathrm{mL})$ & $29.3 \pm 2.69$ & $24.9 \pm 1.95$ & $0.091^{\mathrm{a}}$ \\
\hline Very low density lipoprotein (VLDL) cholesterol (mg/dL) & $24.1 \pm 15.25$ & $23.1 \pm 13.76$ & $0.453^{\mathrm{a}}$ \\
\hline
\end{tabular}


Table 1. Cont.

\begin{tabular}{|c|c|c|c|}
\hline & \multicolumn{2}{|c|}{ Serum 25(OH)D Concentration * } & \multirow[b]{2}{*}{$p$ Value } \\
\hline & $\begin{array}{l}\text { Deficient/Insufficient } \\
\qquad(n=182)\end{array}$ & $\begin{array}{l}\text { Optimal } \\
(n=214)\end{array}$ & \\
\hline Total cholesterol $(\mathrm{mg} / \mathrm{dL})$ & $190.2 \pm 40.12$ & $188.0 \pm 37.12$ & $0.977^{\mathrm{a}}$ \\
\hline High density lipoprotein (HDL) cholesterol (mg/dL) & $48.6 \pm 11.55$ & $48.8 \pm 11.57$ & $0.440^{\mathrm{a}}$ \\
\hline Low density lipoprotein (LDL) cholesterol (mg/dL) & $123.9 \pm 31.20$ & $122.2 \pm 28.72$ & $0.913^{\mathrm{a}}$ \\
\hline Triglyceride $(\mathrm{mg} / \mathrm{dL})$ & $120.7 \pm 76.35$ & $115.7 \pm 68.74$ & $0.440^{\mathrm{a}}$ \\
\hline Adiponectin (ng/mL) & $10480.1 \pm 6217.49$ & $10626 \pm 6692.54$ & $0.556^{\mathrm{a}}$ \\
\hline Insulin resistance (HOMA-IR) & $1.8 \pm 0.09$ & $1.6 \pm 0.07$ & $0.058^{\mathrm{a}}$ \\
\hline \multicolumn{4}{|l|}{ Dietary intake } \\
\hline Total energy (kcal) & $2429.3 \pm 1093.98$ & $2368.0 \pm 992.98$ & $0.675^{\mathrm{a}}$ \\
\hline Carbohydrate $(\%)$ & $46.7 \pm 8.90$ & $45.3 \pm 9.73$ & $0.073^{\mathrm{a}}$ \\
\hline Protein $(\%)$ & $15.5 \pm 3.68$ & $15.7 \pm 4.83$ & $0.207^{\mathrm{a}}$ \\
\hline Fat $(\%)$ & $37.5 \pm 7.66$ & $38.9 \pm 8.41$ & $0.098^{\mathrm{a}}$ \\
\hline Total fibre $(\mathrm{g})$ & $23.9 \pm 10.95$ & $23.7 \pm 11.31$ & $0.382^{\mathrm{a}}$ \\
\hline \multicolumn{4}{|l|}{ Physical activity level, $n(\%)$} \\
\hline Sedentary & $68(37.4)$ & $84(39.3)$ & $0.306^{b}$ \\
\hline Moderate & $90(49.5)$ & $112(52.3)$ & \\
\hline Vigorous & $24(13.1)$ & $18(8.4)$ & \\
\hline
\end{tabular}

Data are represented as means \pm SD for anthropometric measurements, biochemical parameters, and dietary intake; and as number (percentage) for physical activity level. ${ }^{a}$ Independent sample $t$ test, ${ }^{b}$ Pearson chi-square test. * Cut-off point for serum vitamin D level was based on the recommendation of the Institute of Medicine.

\subsection{Association of Vitamin D Status with Metabolic Traits}

After adjusting for potential confounders, the serum 25(OH)D concentration was significantly associated with the fasting insulin $(p=0.011)$ and HOMA-IR $(p=0.010)$ (Figure S1) and, none of the other phenotypic associations were statistically significant (Table S2).

\subsection{Genetic Association of Metabolic-GRS with Metabolic Traits and Serum} 25(OH)D Concentrations

Metabolic-GRS was significantly associated with the serum $25(\mathrm{OH}) \mathrm{D}$ concentration ( $p=0.020)$, where participants carrying $\geq 1$ risk allele had lower serum $25(\mathrm{OH}) \mathrm{D}$ levels $(23.5 \pm 0.89 \mathrm{ng} / \mathrm{mL})$ compared to those carrying $<1$ risk allele $(27.9 \pm 1.96 \mathrm{ng} / \mathrm{mL})$ (Figure 1). None of the other characteristics differed significantly between the two GRS groups ( $<1$ risk allele vs. $\geq 1$ risk allele) ( $p>0.05$, for all associations) (Table S3).

\subsection{Interaction between Metabolic-GRS and Serum 25(OH)D Concentration on Clinical and Biochemical Outcomes}

There was no significant interaction between metabolic-GRS and vitamin D concentrations on metabolic traits $(p>0.05)$ (Table S4).

\subsection{Interaction between Metabolic-GRS and Dietary Intake on Serum Vitamin D Concentration}

There was a significant interaction between metabolic-GRS and dietary energy from fat intake on serum $25(\mathrm{OH}) \mathrm{D}$ concentrations after adjusting for age, gender, and obesity status, and months of measurement ( $p=0.040$, Figure 2). Participants in the highest tertile of fat intake $(122.3 \pm 52.51 \mathrm{~g} / \mathrm{d})$ and carrying $\geq 1$ risk allele had significantly lower serum $25(\mathrm{OH}) \mathrm{D}$ concentrations compared to the participants having the highest tertile of fat intake and carrying $<1$ risk allele $(p=0.006)$ (Figure 2). No significant interactions between metabolic-GRS and dietary intakes of other macronutrients on serum $25(\mathrm{OH}) \mathrm{D}$ were obtained ( $p>0.05$, for each) (Table S5). 


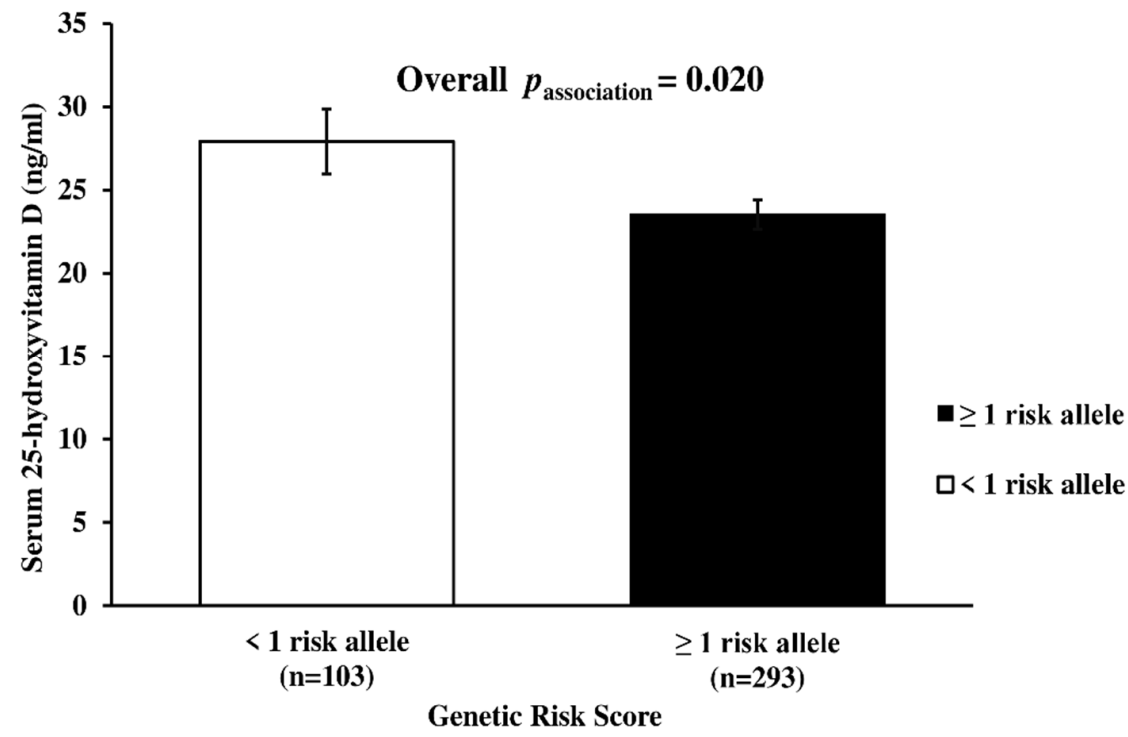

Figure 1. Association between the serum 25-Hydroxy-Vitamin D level and metabolic-GRS. Individuals having 1 or more risk allele had lower serum 25(OH)D concentrations compared to participants with $<1$ risk allele. The mean and standard deviation for the serum $25(\mathrm{OH}) \mathrm{D}$ level was $27.9 \pm 1.96 \mathrm{ng} / \mathrm{mL}$ in participants with $<1$ risk allele, while it was $23.5 \pm 0.89 \mathrm{ng} / \mathrm{mL}$ in participants with $\geq 1$ risk allele. $P$ value was calculated using linear regression analysis after adjusting for age, gender, obesity status, and months of measurement.

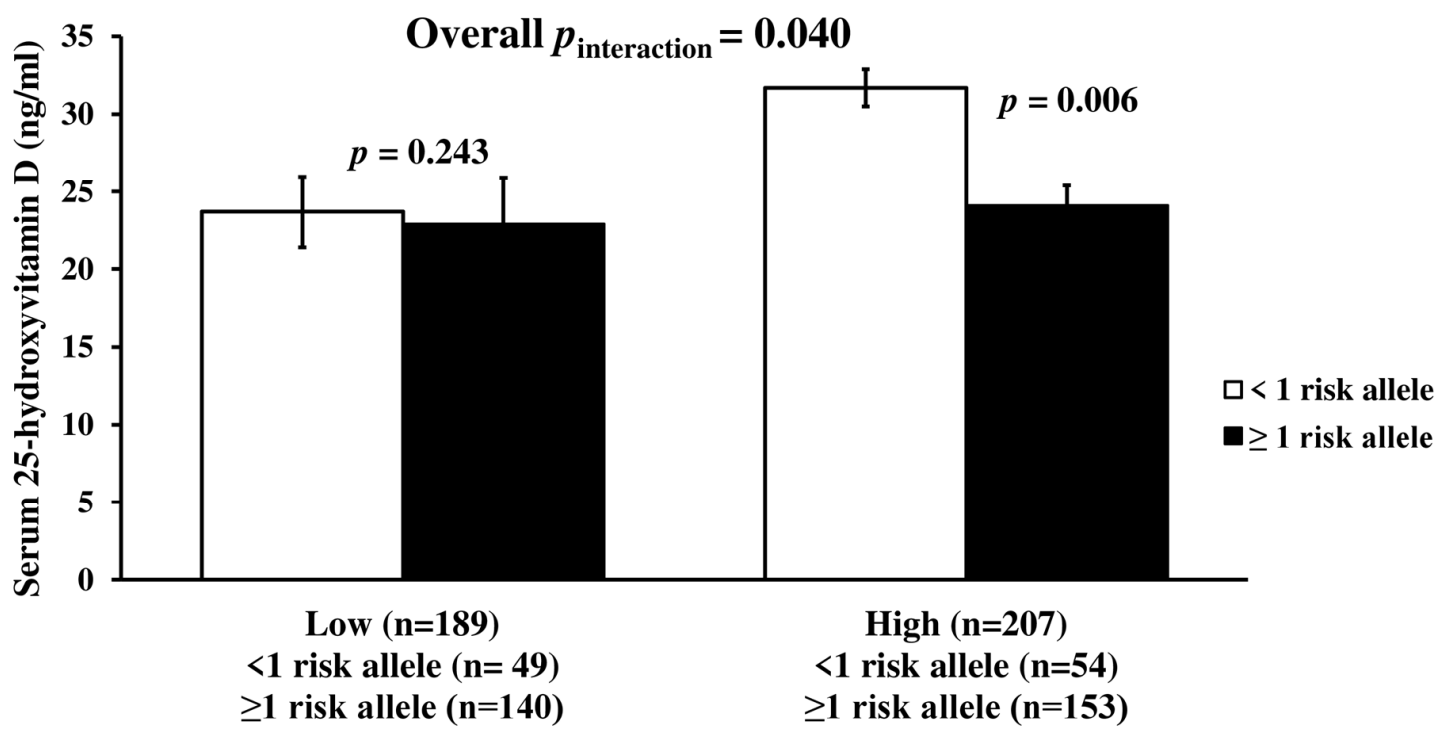

Fat intake (\%)

Figure 2. Interaction between metabolic-GRS and fat intake (\%) on serum $25(\mathrm{OH}) \mathrm{D}$ concentration. There was a significant interaction of the GRS with dietary fat intake on serum 25-hydroxyvitamin $\mathrm{D}$ level. Among those with $\geq 1$ risk alleles, individuals with a high of fat intake had a lower serum 25-hydroxyvitamin D level ( $p=0.006)$. Vitamin D level was $23.1 \pm 1.06 \mathrm{ng} / \mathrm{mL}$ among those with low fat intake: For individuals without risk allele: $23.7 \pm 2.29$; for individuals with risk allele: $22.9 \pm 1.19 \mathrm{ng} / \mathrm{mL}$. It was $26.1 \pm 1.26 \mathrm{ng} / \mathrm{mL}$ among those with a high fat intake (for $<1$ risk allele: $31.7 \pm 3.03$; for $\geq 1$ risk alleles: $24.1 \pm 1.30 \mathrm{ng} / \mathrm{mL}$ ). The median value of dietary fat intake was $38 \%$. The mean intake of low-fat intake was $31.6 \pm 4.61 \%$ (for individuals without risk allele: $31.7 \pm 4.89 \%$; for individuals having $\geq 1$ risk alleles: $31.6 \pm 4.52 \%$ ). The mean intake of high fat intake was $44.4 \pm 5.32 \%$ (for $<1$ risk allele: $45.1 \pm 5.46 \%$; for $\geq 1$ risk alleles: $44.1 \pm 5.26 \%$ ). $p$ values were derived from linear regression analysis and adjusted for age, gender, obesity status, and months of measurement. 


\section{Discussion}

To date, our study is the first to use a nutrigenetic approach to investigate the interaction between metabolic-GRS and dietary intakes on serum 25(OH)D levels in a Turkish population. This study proposed a novel interaction between metabolic-GRS and dietary fat intake on serum $25(\mathrm{OH}) \mathrm{D}$ concentrations by demonstrating that participants with high metabolic-GRS and higher dietary fat intake had significantly lower serum 25(OH)D levels compared to the participants with high metabolic-GRS but lower dietary fat intake. Given the high prevalence of VDD in Turkey [8,9], these results might have public health significance in preventing VDD in those with high metabolic genetic risk. Therefore, following the current dietary fat intake recommendations $(<35 \%)[52,53]$ might be important to maintain the optimal vitamin D status, especially in individuals who have a genetic risk of VDD.

Studies that examined the link between metabolic disease associated gene variants and vitamin D status are limited and the findings have been conflicting [25,35]. A recent study conducted in 545 Asian Indians showed no significant association between metabolic-GRS and serum 25(OH)D concentration [25]. On the other hand, Alathari et al. [35] found that Southeast Asian women carrying $<4$ metabolic risk alleles had higher serum $25(\mathrm{OH}) \mathrm{D}$ concentration compared to the individuals carrying four or more risk alleles. Similarly, our study has shown that individuals having $\geq 1$ metabolic risk allele had lower serum $25(\mathrm{OH}) \mathrm{D}$ concentrations than the individuals not having any risk allele. Despite the limited evidence on the link between metabolic disease-associated gene variants and vitamin $D$ levels, many genetic association studies investigated the associations of vitamin D-related SNPs that can modify the activation, catabolism, and transport of vitamin D, with metabolic traits. However, the findings of these studies were also inconsistent [22,54-56]. For instance, a couple of studies conducted in European populations showed no association between the gene variants of the vitamin D binding protein/group-specific component (DBP/GC) and the risk of diabetes [54,55], while significant associations have been demonstrated in Asian populations [56]. The discrepancies in the findings of different studies could be explained by the diversity in the number of SNPs, ethnicity, culture, and socioeconomic status.

The present study examined whether the genetic risk of metabolic diseases has been affected by VDD and found no significant interaction between metabolic-GRS and the serum $25(\mathrm{OH}) \mathrm{D}$ level on metabolic traits. Similarly, a study that examined the interactions between the vitamin D receptor SNPs and serum vitamin D level on metabolic disease related traits in 5160 Europeans failed to show any evidence of vitamin D-related gene variations modifying the interaction between $25(\mathrm{OH}) \mathrm{D}$ concentrations and metabolic traits [57]. Other studies also confirmed the lack of any associations between genetically instrumented serum 25(OH)D concentrations and metabolic traits, such as BMI [35,58,59], waist circumference [35,58-60], glycated hemoglobin [35,61], fasting insulin [35,61], and glucose levels $[35,61,62]$.

The World Health Organization Noncommunicable Diseases Progress Monitor (2017) declared that Non-Communicable Diseases (NCDs) have been responsible for $88 \%$ of deaths in the Turkish population [63]. Targeting modifiable risk factors for NCDs including the dietary modifications for obesity could prevent mortality [36,64,65]. The present study found that dietary fat intake and metabolic-GRS had an interaction on vitamin D concentrations, and the level of serum $25(\mathrm{OH}) \mathrm{D}$ was lower in those carrying risk allele and consuming a high amount of dietary fat. The high amount $(\geq 38 \%=122.3 \pm 52.51 \mathrm{~g} / \mathrm{d})$ was defined according to the median of total dietary fat intake in the study population. This cut off value also meets the high dietary fat intake as defined by the recommendations of WHO (15-30\%), IOM (20-35\%), and Turkish Dietary Guidelines (20-35\%) [52,53,66]. Vitamin D is a fat-soluble vitamin and absorbed with dietary fat by passive diffusion therefore, dietary fat can have a potential to modify the interaction between the genetic risk of metabolic disease and vitamin D status [67]. Similar to current findings, it was shown that high fat diet-induced obesity resulted in lower serum 25(OH)D levels in an animal study [68]. To date, there have been only two studies that have examined the metabolic-GRS- diet interactions on serum $25(\mathrm{OH}) \mathrm{D}$ concentrations $[25,35]$. The first study examined whether 
any dietary factor could modify the relationship between the serum $25(\mathrm{OH}) \mathrm{D}$ concentration and metabolic traits in 545 Asian Indians. In discordance with the findings of our study, they showed that individuals with low GRS (GRS $\leq 1)$ and lower dietary carbohydrate intake $(\leq 62 \%)$ had higher serum $25(\mathrm{OH}) \mathrm{D}$ concentrations [25]. Furthermore, the study generated the GRS using five SNPs from three genes (FTO, TCF7L2, and MC4R), and the energy from carbohydrate, protein, and fat was $64 \%, 11 \%$, and $23 \%$, respectively. The second study tested a similar hypothesis in Southeast Asian Minangkabau women using two GRSs constructed based on 15 SNPs from vitamin D and metabolic disease-associated genes, respectively, and showed no significant interaction between metabolic-GRS and dietary intake on one's vitamin D status [35]. Some of the reasons for the discrepancy in the findings across the studies might be the number of SNPs that were used in the GRS, ethnicity, and the diversity in the dietary macronutrient intake patterns. Given these ethnic-specific findings, meeting the current dietary recommendations for macronutrient intake might be more essential in individuals with a known genetic risk to help maintain a healthy vitamin D status $[52,53,66]$.

Several hypotheses have been proposed to define the potential mechanisms of the associations between metabolic diseases including obesity and one's vitamin D status [69-78]. These include the volumetric dilution of serum vitamin D levels $[68,73,74]$, adipocyte hypertrophy contributing to overexpression of proinflammatory cytokines [77,79], modifications of vitamin D-related enzymes [75,76] affected by high fat diet-induced obesity, and lower endogenous vitamin D synthesis in the skin as a consequence of less outdoor activity [75,80], less physical activity [71], and less exposure to sunlight in obese individuals [73-80]. In addition, the bi-directional Mendelian randomisation analysis conducted in 42,024 Europeans showed a relationship between vitamin D status and obesity, suggesting that higher BMI leads to lower vitamin D levels where a $4.2 \%$ decrease in serum $25(\mathrm{OH}) \mathrm{D}$ concentrations was observed for every $10 \%$ increase in BMI [22]. The Framingham Study also showed that the prevalence of VDD was higher among individuals with a higher BMI [81]. Furthermore, a lifestyle intervention study conducted in obese individuals demonstrated that serum $25(\mathrm{OH}) \mathrm{D}$ concentrations were significantly increased as a consequence of weight loss [82]. Despite these findings, some studies failed to show any association between vitamin $\mathrm{D}$ status and metabolic traits [83-85]. For instance, Larsen et al. [83] showed no or marginal associations between the serum 25(OH)D level and biomarkers of adiposity in 10,898 individuals comprising Danish, British, and Finnish participants. Similarly, independent of the genetic associations, our study also has not shown either any difference in metabolic traits by vitamin $\mathrm{D}$ status, or any association between obesity-related traits and the serum $25(\mathrm{OH}) \mathrm{D}$ level. The inconsistencies among the studies might depend on the potential predisposition to bias and confounding factors (e.g., the time and amount of sunlight exposure, physical activity level, more clothing, skin colour, and ethnicity) in observational study designs conducted in different populations. Furthermore, the differences in the categorisation of vitamin D status and the measures of obesity including BMI, body weight, and waist circumference might be the other reason for the inconsistency [86]. Genetic studies can provide more consistent findings in the exploration of the association between vitamin D status and metabolic traits, because the bias and confounding factors can be partly eliminated with this approach $[26,87]$.

The main strengths of this study were the use of several biochemical markers related to metabolic traits and a well-characterised study cohort. In addition, the construction and use of a GRS method rather than a single SNP approach enhances the statistical power and presents an efficient perspective for metabolic outcomes [88-90]. However, there are some limitations that need to be acknowledged. Firstly, the study did not measure exposure to sunlight, and the data collection period only covered summer and autumn seasons. For overcoming this limitation, the months of measurement was adjusted as a confounding factor in all the analyses. Secondly, the small sample size might be considered as a further limitation of the study however, our study has been able to confirm previously reported associations and identify gene-diet interactions. Thirdly, dietary intake was assessed using 
a 24-h dietary recall method, which is prone to self-reporting bias however, this method is used commonly in nutrigenetic studies and the method could be applied to diverse groups with a wide range of eating habits. Fourthly, we could not examine the causative effects due to limitations of the cross-sectional study design. Lastly, although analysis undertaken was adjusted for potential confounders, we cannot rule out the impact of residual confounders caused by unknown variables.

\section{Conclusions}

In summary, our study provided evidence for a novel interaction between metabolicGRS and dietary fat intake on serum vitamin D concentrations, suggesting that following current dietary fat intake recommendations $(<35 \%)$ might be effective to prevent any consequences of the genetic risk of VDD. However, further larger studies are needed to endorse this interaction before generalising the findings to the Turkish population and implementing any personalised dietary recommendations for the maintenance of one's optimal vitamin D status.

Supplementary Materials: The following supporting information can be downloaded at: https: / / www.mdpi.com/article/10.3390/nu14020382/s1, Figure S1: Association of 25(OH)D concentrations with metabolic traits, Table S1. Genotype frequencies of TCF7L2 and MC4R SNPs, Table S2. Association between the serum 25(OH)D concentration and metabolic traits, Table S3. Metabolic-GRS and baseline characteristics of the study participants, Table S4. The interaction between metabolicGRS and serum 25(OH) D on metabolic traits, Table S5. The interaction between metabolic-GRS and macronutrient intake on the serum $25(\mathrm{OH}) \mathrm{D}$ level.

Author Contributions: K.S.V. conceived the nutrigenetics study; K.S.V., K.I.-A., B.E.A. and Z.B. drafted the manuscript; K.I.-A. performed the statistical analysis; Z.B. and K.S.V. designed the study; K.I.-A., B.T.-D. and Z.B. conducted data collection and desk based analyses; S.N.S. and T.E. carried out the eligibility screening, physical examination and clinical evaluations; I.L. performed the biochemical analysis; M.A. carried out the genetic analysis; K.S.V., Z.B., B.E.A. and B.E. critically reviewed the manuscript. All authors contributed to and approved the final version of the manuscript.

Funding: This research was funded by the Scientific and Technological Research Council of Turkey (TUBITAK), grant number 216S272 and the APC was funded by the University of Reading, UK.

Institutional Review Board Statement: The study was conducted according to the guidelines of the Declaration of Helsinki, and approved by the Ethics Committee of Hacettepe University (protocol code: GO 15/612-11 and date of approval: 16 September 2015).

Informed Consent Statement: Informed consent was obtained from all participants involved in the study.

Data Availability Statement: The data supporting reported results in the current study are available from the corresponding author on reasonable request.

Acknowledgments: We thank all study participants for their cooperation. Karani S. Vimaleswaran acknowledges support from the British Nutrition Foundation, and the Public Authority for Applied Education and Training of Kuwait is also acknowledged for the scholarship given to Buthaina AlAthari. Buyuktuncer acknowledges the Scientific and Technological Research Council of Turkey (TUBITAK) and Council of Higher Education of Turkey for the scholarship given to Kubra Isgin-Atici.

Conflicts of Interest: The authors declare no conflict of interest.

\section{References}

1. Sizar, O.; Khare, S.; Goyal, A.; Bansal, P.; Givler, A. Vitamin D Deficiency. StatPearls; StatPearls Publishing: Treasure Island, FL, USA, 2020. Available online: https:/ / pubmed.ncbi.nlm.nih.gov/30335299/ (accessed on 3 March 2021).

2. Cashman, K.D.; Dowling, K.G.; Škrabáková, Z.; Gonzalez-Gross, M.; Valtueña, J.; De Henauw, S.; Moreno, L.; Damsgaard, C.T.; Michaelsen, K.F.; Mølgaard, C.; et al. Vitamin D deficiency in Europe: Pandemic? Am. J. Clin. Nutr. 2016, 103, 1033-1044. [CrossRef] [PubMed] 
3. Aji, A.S.; Erwinda, E.; Rasyid, R.; Yusrawati, Y.; Malik, S.G.; Alathari, B.; Lovegrove, J.A.; Lipoeto, N.I.; Vimaleswaran, K.S. A genetic approach to study the relationship between maternal Vitamin D status and newborn anthropometry measurements: The Vitamin D pregnant mother (VDPM) cohort study. J. Diabetes Metab. Disord. 2020, 19, 91-103. [CrossRef] [PubMed]

4. AlFaris, N.A.; AlKehayez, N.M.; AlMushawah, F.I.; AlNaeem, A.N.; AlAmri, N.D.; AlMudawah, E.S. Vitamin D Deficiency and Associated Risk Factors in Women from Riyadh, Saudi Arabia. Sci. Rep. 2019, 9, 20371. [CrossRef] [PubMed]

5. Kim, S.H.; Oh, J.E.; Song, D.W.; Cho, C.Y.; Hong, S.H.; Cho, Y.J.; Yoo, B.W.; Shin, K.S.; Joe, H.; Shin, H.S.; et al. The factors associated with Vitamin D deficiency in community dwelling elderly in Korea. Nutr. Res. Prac. 2018, 12, 387-395. [CrossRef]

6. Chakhtoura, M.; Rahme, M.; Chamoun, N.; El-Hajj Fuleihan, G. Vitamin D in the Middle East and North Africa. Bone Rep. 2018, 8, 135-146. [CrossRef] [PubMed]

7. Lips, P.; Cashman, K.D.; Lamberg-Allardt, C.; Bischoff-Ferrari, H.A.; Obermayer-Pietsch, B.; Bianchi, M.L.; Stepan, J.; El-Hajj Fuleihan, G.; Bouillon, R. Current vitamin D status in European and Middle East countries and strategies to prevent vitamin D deficiency: A position statement of the European Calcified Tissue Society. Eur. J. Endocrinol. 2019, 180, 23-54. [CrossRef]

8. Alpdemir, M.; Alpdemir, M.F. Vitamin D deficiency status in Turkey: A meta-analysis. Int. J. Med. Biochem. 2019, 2, 118-131. [CrossRef]

9. Göktaş, O.; Ersoy, C.; Ercan, I.; Can, F.E. Vitamin D status in the adult population of Bursa-Turkey. Eur. J. Gen. Pract. 2020, 26, 156-162. [CrossRef]

10. Buyukuslu, N.; Esin, K.; Hizli, H.; Sunal, N.; Yigit, P.; Garipagaoglu, M. Clothing preference affects vitamin D status of young women. Nutr. Res. 2014, 34, 688-693. [CrossRef]

11. Yakar, B.; Kaya, M.O. Vitamin D deficiency during pregnancy in Turkey and the effect of the sunlight: A systematic review and meta-analysis. Turk. J. Biochem. 2021, 46, 129-135. [CrossRef]

12. Alathari, B.E.; Sabta, A.A.; Kalpana, C.A.; Vimaleswaran, K.S. Vitamin D pathway-related gene polymorphisms and their association with metabolic diseases: A literature review. J. Diabetes Metab. Disorders 2020, 19, 1701-1729. [CrossRef]

13. Ebadi, M.; Montano-Loza, A.J. Perspective: Improving vitamin D status in the management of COVID-19. Eur. J. Clin. Nutr. 2020, 74, 856-859. [CrossRef]

14. Zhang, S.; Miller, D.D.; Li, W. Non-Musculoskeletal Benefits of Vitamin D beyond the Musculoskeletal System. Int. J. Mol. Sci. 2021, 22, 2128. [CrossRef] [PubMed]

15. AlQuaiz, A.M.; Alrasheed, A.A.; Kazi, A.; Batais, M.A.; Alhabeeb, K.M.; Jamal, A.; Fouda, M.A. Is 25-Hydroxyvitamin D Associated with Glycosylated Hemoglobin in Patients with Type 2 Diabetes Mellitus in Saudi Arabia? A Population Based Study. Int. J. Environ. Res. Public Health 2021, 18, 2805. [CrossRef] [PubMed]

16. Anderson, J.L.; May, H.T.; Horne, B.D.; Bair, T.L.; Hall, N.L.; Carlquist, J.F.; Lappé, D.L.; Muhlestein, J.B. Relation of Vitamin D Deficiency to Cardiovascular Risk Factors, Disease Status, and Incident Events in a General Healthcare Population. Am. J. Cardiol. 2010, 106, 963-968. [CrossRef]

17. Brock, K.; Huang, W.Y.; Fraser, D.R.; Ke, L.; Tseng, M.; Stolzenberg-Solomon, R.; Peters, U.; Ahn, J.; Purdue, M.; Mason, R.S.; et al. Low vitamin D status is associated with physical inactivity, obesity and low vitamin D intake in a large US sample of healthy middle-aged men and women. J. Steroid Biochem. Mol. Biol. 2010, 121, 462-466. [CrossRef] [PubMed]

18. Manna, P.; Achari, A.E.; Jain, S.K. Vitamin D supplementation inhibits oxidative stress and upregulate SIRT1/AMPK/GLUT4 cascade in high glucose-treated 3T3L1 adipocytes and in adipose tissue of high fat diet-fed diabetic mice. Arch. Biochem. Biophys. 2017, 615, 22-34. [CrossRef] [PubMed]

19. Larrick, B.M.; Kim, K.H.; Donkin, S.S.; Teegarden, D. 1,25-Dihydroxyvitamin D regulates lipid metabolism and glucose utilization in differentiated 3T3-L1 adipocytes. Nutr. Res. 2018, 58, 72-83. [CrossRef]

20. Zemel, M.B. Nutritional and endocrine modulation of intracellular calcium: Implications in obesity, insulin resistance and hypertension. Mol. Cell Biochem. 1998, 188, 129-136. [CrossRef] [PubMed]

21. Maestro, B.; Molero, S.; Bajo, S.; Dávila, N.; Calle, C. Transcriptional activation of the human insulin receptor gene by 1,25dihydroxyvitamin D(3). Cell Biochem. Funct. 2002, 20, 227-232. [CrossRef]

22. Vimaleswaran, K.S.; Berry, D.J.; Lu, C.; Tikkanen, E.; Pilz, S.; Hiraki, L.T.; Cooper, J.D.; Dastani, Z.; Li, R.; Houston, D.K. Causal relationship between obesity and vitamin D status: Bi-directional Mendelian randomization analysis of multiple cohorts. PLoS Med. 2013, 10, e1001383. [CrossRef] [PubMed]

23. Saneei, P.; Salehi-Abargouei, A.; Esmaillzadeh, A. Serum 25-hydroxy vitamin D levels in relation to body mass index: A systematic review and meta-analysis. Obes. Rev. 2013, 14, 393-404. [CrossRef]

24. Al-Dabhani, K.; Tsilidis, K.K.; Murphy, N.; Ward, H.A.; Elliott, P.; Riboli, E.; Gunter, M.; Tzoulaki, I. Prevalence of vitamin D deficiency and association with metabolic syndrome in a Qatari population. Nutr. Diabetes 2017, 7, e263. [CrossRef] [PubMed]

25. Alathari, B.E.; Bodhini, D.; Jayashri, R.; Lakshmipriya, N.; Shanthi Rani, C.S.; Sudha, V.; Lovegrove, J.A.; Anjana, R.M.; Mohan, V.; Radha, V.; et al. A Nutrigenetic Approach to Investigate the Relationship between Metabolic Traits and Vitamin D Status in an Asian Indian Population. Nutrients 2020, 12, 1357. [CrossRef]

26. Jiang, X.; Kiel, D.P.; Kraft, P. The genetics of vitamin D. Bone 2019, 126, 59-77. [CrossRef] [PubMed]

27. Wang, J.; Hu, F.; Feng, T.; Zhao, J.; Yin, L.; Li, L.; Wang, Y.; Wang, Q.; Hu, D. Meta-analysis of associations between TCF7L2 polymorphisms and risk of type 2 diabetes mellitus in the Chinese population. BMC Med. Genet. 2013, 14, 8. [CrossRef] [PubMed] 
28. Adeyemo, A.A.; Tekola-Ayele, F.; Doumatey, A.P.; Bentley, A.R.; Chen, G.; Huang, H.; Zhou, J.; Shriner, D.; Fasanmade, O.; Okafor, G.; et al. Evaluation of Genome Wide Association Study Associated Type 2 Diabetes Susceptibility Loci in Sub Saharan Africans. Front. Genet. 2015, 6, 335. [CrossRef]

29. El Hajj Chehadeh, S.; Osman, W.; Nazar, S.; Jerman, L.; Alghafri, A.; Sajwani, A.; Alawlaqi, M.; AlObeidli, M.; Jelinek, H.F.; AlAnouti, F.; et al. Implication of genetic variants in overweight and obesity susceptibility among the young Arab population of the United Arab Emirates. Gene 2020, 739, 144509. [CrossRef]

30. Ouhaibi-Djellouli, H.; Mediene-Benchekor, S.; Lardjam-Hetraf, S.A.; Hamani-Medjaoui, I.; Meroufel, D.N.; Boulenouar, H.; Hermant, X.; Saidi-Mehtar, N.; Amouyel, P.; Houti, L.; et al. The TCF7L2 rs7903146 polymorphism, dietary intakes and type 2 diabetes risk in an Algerian population. BMC Genet. 2014, 15, 134. [CrossRef]

31. Loos, R.J.; Lindgren, C.M.; Li, S.; Wheeler, E.; Zhao, J.H.; Prokopenko, I.; Inouye, M.; Freathy, R.M.; Attwood, A.P.; Beckmann, J.S.; et al. Common variants near MC4R are associated with fat mass, weight and risk of obesity. Nat. Genet. 2008, 40, 768-775. [CrossRef] [PubMed]

32. Gao, L.; Wang, L.; Yang, H.; Pan, H.; Gong, F.; Zhu, H. MC4R Single Nucleotide Polymorphisms Were Associated with Metabolically Healthy and Unhealthy Obesity in Chinese Northern Han Populations. Int. J. Endocrinol. 2019, $2019,4328909$. [CrossRef]

33. O'Beirne, S.L.; Salit, J.; Rodriguez-Flores, J.L.; Staudt, M.R.; Abi Khalil, C.; Fakhro, K.A.; Robay, A.; Ramstetter, M.D.; Al-Azwani, I.K.; Malek, J.A.; et al. Type 2 Diabetes Risk Allele Loci in the Qatari Population. PLoS ONE 2016, 11, e0156834. [CrossRef]

34. Kalantari, S.; Sharafshah, A.; Keshavarz, P.; Davoudi, A.; Habibipour, R. Single and multi-locus association study of TCF7L2 gene variants with susceptibility to type 2 diabetes mellitus in an Iranian population. Gene 2019, 696, 88-94. [CrossRef]

35. Alathari, B.E.; Aji, A.S.; Ariyasra, U.; Sari, S.R.; Tasrif, N.; Yani, F.F.; Sudji, I.R.; Lovegrove, J.A.; Lipoeto, N.I.; Vimaleswaran, K.S. Interaction between Vitamin D-Related Genetic Risk Score and Carbohydrate Intake on Body Fat Composition: A Study in Southeast Asian Minangkabau Women. Nutrients. 2021, 13, 326. [CrossRef]

36. Alsulami, S.; Nyakotey, D.A.; Dudek, K.; Bawah, A.M.; Lovegrove, J.A.; Annan, R.A.; Ellahi, B.; Vimaleswaran, K.S. Interaction between Metabolic Genetic Risk Score and Dietary Fatty Acid Intake on Central Obesity in a Ghanaian Population. Nutrients 2020, 12, 1906. [CrossRef] [PubMed]

37. Cai, J.; Zhang, Y.; Nuli, R.; Zhang, Y.; Abudusemaiti, M.; Kadeer, A.; Tian, X.; Xiao, H. Interaction between dietary patterns and TCF7L2 polymorphisms on type 2 diabetes mellitus among Uyghur adults in Xinjiang Province, China. Diabetes. Metab. Syndr. Obes 2019, 12, 239-255. [CrossRef] [PubMed]

38. Speliotes, E.K.; Willer, C.J.; Berndt, S.I.; Monda, K.L.; Thorleifsson, G.; Jackson, A.U.; Allen, H.L.; Lindgren, C.M.; Luan, J.a.; Mägi, R.; et al. Association analyses of 249,796 individuals reveal 18 new loci associated with body mass index. Nat. Genet. 2010, 42, 937-948. [CrossRef] [PubMed]

39. Ding, W.; Xu, L.; Zhang, L.; Han, Z.; Jiang, Q.; Wang, Z.; Jin, S. Meta-analysis of association between TCF7L2 polymorphism rs7903146 and type 2 diabetes mellitus. BMC Med. Genet. 2018, 19, 38. [CrossRef]

40. Isgin-Atici, K.; Alsulami, S.; Turan-Demirci, B.; Surendran, S.; Sendur, S.N.; Lay, I.; Karabulut, E.; Ellahi, B.; Lovegrove, J.A.; Alikasifoglu, M.; et al. FTO gene-lifestyle interactions on serum adiponectin concentrations and central obesity in a Turkish population. Int. J. Food Sci. Nutr. 2021, 72, 375-385. [CrossRef]

41. Vimaleswaran, K.S. A nutrigenetics approach to study the impact of genetic and lifestyle factors on cardiometabolic traits in various ethnic groups: Findings from the GeNuIne Collaboration. Proc. Nutr. Soc. 2020, 79, 194-204. [CrossRef]

42. Vimaleswaran, K.S. Gene-nutrient interactions on metabolic diseases: Findings from the GeNuIne Collaboration. Nutr. Bull. 2017, 42, 80-86. [CrossRef]

43. World Health Organization. Body Mass Index. 2008. Available online: https://www.euro.who.int/en/health-topics/diseaseprevention/nutrition/a-healthy-lifestyle/body-mass-index-bmi (accessed on 31 August 2021).

44. World Health Organization. Waist Circumference and Waist-Hip Ratio. Report of a WHO Expert Consultation, Geneva, 8-11 December 2008. 2011. Available online: https://apps.who.int/iris/handle/10665/44583. (accessed on 31 August 2021).

45. Peltz, G.; Aguirre, M.T.; Sanderson, M.; Fadden, M.K. The role of fat mass index in determining obesity. Am. J. Hum. Biol. 2010, 22, 639-647. [CrossRef]

46. Ross, A.C.; Manson, J.E.; Abrams, S.A.; Aloia, J.F.; Brannon, P.M.; Clinton, S.K.; Durazo-Arvizu, R.A.; Gallagher, J.C.; Gallo, R.L.; Jones, G.; et al. The 2011 report on dietary reference intakes for calcium and vitamin D from the Institute of Medicine: What clinicians need to know. J. Clin. Endocrinol. Metab. 2011, 96, 53-58. [CrossRef]

47. Bonora, E.; Formentini, G.; Calcaterra, F.; Lombardi, S.; Marini, F.; Zenari, L.; Saggiani, F.; Poli, M.; Perbellini, S.; Raffaelli, A. HOMA-estimated insulin resistance is an independent predictor of cardiovascular disease in type 2 diabetic subjects: Prospective data from the Verona Diabetes Complications Study. Diabetes Care 2002, 25, 1135-1141. [CrossRef]

48. Frese, E.M.; Fick, A.; Sadowsky, H.S. Blood pressure measurement guidelines for physical therapists. Cardiopulm. Phys. Ther. J. 2011, 22, 5-12. [CrossRef]

49. Rakicioglu, N.; Tek Acar, N.; Ayaz, A.; Pekcan, G. Photograph Catalog of Food and Dishes: Portion Sizes and Amounts, 2nd ed.; Ata Ofset Pub: Ankara, Turkey, 2009.

50. Saglam, M.; Arikan, H.; Savci, S.; Inal-Ince, D.; Bosnak-Guclu, M.; Karabulut, E.; Tokgozoglu, L. International physical activity questionnaire: Reliability and validity of the Turkish version. Percept. Mot. Skills 2010, 111, 278-284. [CrossRef] [PubMed]

51. IPAQ Scoring Protocol. Available online: https:// sites.google.com/site/theipaq/scoring-protocol (accessed on 10 May 2021). 
52. Institutes of Medicine (IOM) (2002/2005) Panel on Macronutrients, Panel on the Definition of Dietary Fiber, Subcommittee on Upper Reference Levels of Nutrients, Subcommittee on Interpretation and Uses of Dietary Reference Intakes, and the Standing Committee on the Scientific Evaluation of Dietary Reference Intakes. DRI Dietary Reference Intakes for Energy, Carbohydrate, Fiber, Fat, Fatty Acids, Cholesterol, Protein, and Amino Acids. 2005. Available online: https://www.nal.usda.gov/sites/default/ files/fnic_uploads/energy_full_report.pdf (accessed on 22 April 2021).

53. World Health Organisation. Diet, Nutrition and the Prevention of Chronic Diseases. Report of a Joint WHO/FAO Expert Consultation. 2003. Available online: http:/ / apps.who.int/iris/bitstream/handle/10665/42665/WHO_TRS_916.pdf?sequence=1 (accessed on 10 May 2021).

54. Lu, L.; Bennett, D.A.; Millwood, I.Y.; Parish, S.; McCarthy, M.I.; Mahajan, A.; Lin, X.; Bragg, F.; Guo, Y.; Holmes, M.V.; et al. Association of vitamin $\mathrm{D}$ with risk of type 2 diabetes: A Mendelian randomisation study in European and Chinese adults. PLoS Med. 2018, 15, e1002566. [CrossRef]

55. Buijsse, B.; Boeing, H.; Hirche, F.; Weikert, C.; Schulze, M.B.; Gottschald, M.; Kühn, T.; Katzke, V.A.; Teucher, B.; Dierkes, J.; et al. Plasma 25-hydroxyvitamin D and its genetic determinants in relation to incident type 2 diabetes: A prospective case-cohort study. Eur. J. Epidemiol. 2013, 28, 743-752. [CrossRef]

56. Wang, G.; Li, Y.; Li, L.; Yu, F.; Cui, L.; Ba, Y.; Li, W.; Wang, C. Association of the vitamin D binding protein polymorphisms with the risk of type 2 diabetes mellitus: A meta-analysis. BMJ Open 2014, 4, e005617. [CrossRef] [PubMed]

57. Vimaleswaran, K.S.; Power, C.; Hyppönen, E. Interaction between vitamin D receptor gene polymorphisms and 25hydroxyvitamin D concentrations on metabolic and cardiovascular disease outcomes. Diabetes Metab. 2014, 40, 386-389. [CrossRef]

58. Shen, F.; Wang, Y.; Sun, H.; Zhang, D.; Yu, F.; Yu, S.; Han, H.; Wang, J.; Ba, Y.; Wang, C.; et al. Vitamin D receptor gene polymorphisms are associated with triceps skin fold thickness and body fat percentage but not with body mass index or waist circumference in Han Chinese. Lipids Health Dis. 2019, 18, 97. [CrossRef] [PubMed]

59. Khan, R.J.; Riestra, P.; Gebreab, S.Y.; Wilson, J.G.; Gaye, A.; Xu, R.; Davis, S.K. Vitamin D Receptor Gene Polymorphisms Are Associated with Abdominal Visceral Adipose Tissue Volume and Serum Adipokine Concentrations but Not with Body Mass Index or Waist Circumference in African Americans: The Jackson Heart Study. J. Nutr. 2016, 146, 1476-1482. [CrossRef] [PubMed]

60. Chen, C.; Chen, Y.; Weng, P.; Xia, F.; Li, Q.; Zhai, H.; Wang, N.; Lu, Y. Association of 25-hydroxyvitamin D with cardiometabolic risk factors and metabolic syndrome: A mendelian randomization study. Nutr. J. 2019, 18, 61. [CrossRef]

61. Mackawy, A.M.H.; Badawi, M.E.H. Association of vitamin D and vitamin D receptor gene polymorphisms with chronic inflammation, insulin resistance and metabolic syndrome components in type 2 diabetic Egyptian patients. Meta Gene 2014, 2, 540-556. [CrossRef]

62. Karonova, T.; Grineva, E.; Belyaeva, O.; Bystrova, A.; Jude, E.B.; Andreeva, A.; Kostareva, A.; Pludowski, P. Relationship Between Vitamin D Status and Vitamin D Receptor Gene Polymorphisms With Markers of Metabolic Syndrome Among Adults. Front. Endocrinol. 2018, 9, 448. [CrossRef] [PubMed]

63. World Health Organisation. National Household Health Survey_Prevalence of Noncommunicable Disease Risk Factors in Turkey 2017-2018. Available online: https://www.euro.who.int/en/countries/turkey/publications/national-household-healthsurvey-prevalence-of-noncommunicable-disease-risk-factors-in-turkey-2017--2018 (accessed on 21 April 2021).

64. Freire, R.D.; Cardoso, M.A.; Gimeno, S.G.A.; Ferreira, S.R.G. Dietary Fat Is Associated with Metabolic Syndrome in Japanese Brazilians. Diabetes Care 2005, 28, 1779-1785. [CrossRef]

65. Narasimhan, S.; Nagarajan, L.; Vaidya, R.; Gunasekaran, G.; Rajagopal, G.; Parthasarathy, V.; Unnikrishnan, R.; Anjana, R.M.; Mohan, V.; Sudha, V. Dietary fat intake and its association with risk of selected components of the metabolic syndrome among rural South Indians. Indian J. Endocrinol. Metab. 2016, 20, 47-54. [PubMed]

66. Turkey Dietary Guidelines; Ministry of Health of Turkey Publication. No: 1046; Ministry of Turkey Health Publication: Ankara, Turkey, 2016. Available online: https://dosyasb.saglik.gov.tr/Eklenti/10922,17ocaktuberingilizcepdf.pdf?0 (accessed on 2 April 2021).

67. Ross, A.C.; Taylor, C.L.; Yaktine, A.L.; Del Valle, H.B. Dietary Reference Intakes for Calcium and Vitamin D; National Academies Press: Washington, DC, USA, 2011. Available online: https://www.ncbi.nlm.nih.gov/books/NBK56070/ (accessed on 22 May 2021).

68. Park, C.Y.; Shin, Y.; Kim, J.-H.; Zhu, S.; Jung, Y.S.; Han, S.N. Effects of high fat diet-induced obesity on vitamin D metabolism and tissue distribution in vitamin D deficient or supplemented mice. Nutr. Metab. 2020, 17, 44. [CrossRef]

69. Szymczak-Pajor, I.; Śliwińska, A. Analysis of Association between Vitamin D Deficiency and Insulin Resistance. Nutrients 2019, 11, 794. [CrossRef]

70. dos Santos, L.R.; Lima, A.G.A.; Braz, A.F.; de Sousa Melo, S.R.; Morais, J.B.S.; Severo, J.S.; de Oliveira, A.R.S.; Cruz, K.J.C.; do Nascimento Marreiro, D. Role of vitamin D in insulin resistance in obese individuals. Nutrire 2017, 42, 17. [CrossRef]

71. Mitri, J.; Muraru, M.D.; Pittas, A.G. Vitamin D and type 2 diabetes: A systematic review. Eur. J. Clin. Nutr. 2011, 65, 1005-1015. [CrossRef]

72. Mirhosseini, N.; Vatanparast, H.; Mazidi, M.; Kimball, S.M. The Effect of Improved Serum 25-Hydroxyvitamin D Status on Glycemic Control in Diabetic Patients: A Meta-Analysis. J. Clin. Endocrinol. Metab. 2017, 102, 3097-3110. [CrossRef]

73. Pourshahidi, L.K. Vitamin D and obesity: Current perspectives and future directions. Proc. Nutr. Soc. 2014, 74, 115-124. [CrossRef] [PubMed] 
74. Rafiq, S.; Jeppesen, P.B. Body Mass Index, Vitamin D, and Type 2 Diabetes: A Systematic Review and Meta-Analysis. Nutrients 2018, 10, 1182. [CrossRef] [PubMed]

75. De Oliveira, L.F.; de Azevedo, L.G.; da Mota Santana, J.; de Sales, L.P.C.; Pereira-Santos, M. Obesity and overweight decreases the effect of vitamin D supplementation in adults: Systematic review and meta-analysis of randomized controlled trials. Rev. Endocr. Metab. Disord. 2020, 21, 67-76. [CrossRef]

76. Park, J.M.; Park, C.Y.; Han, S.N. High fat diet-Induced obesity alters vitamin D metabolizing enzyme expression in mice. Biofactors 2015, 41, 175-182. [CrossRef]

77. Cannell, J.J.; Grant, W.B.; Holick, M.F. Vitamin D and inflammation. Dermatoendocrinol 2015, 6, e983401. [CrossRef] [PubMed]

78. Park, J.E.; Pichiah, P.B.T.; Cha, Y.-S. Vitamin D and Metabolic Diseases: Growing Roles of Vitamin D. J. Obes. Metab. Syndr. 2018, 27, 223-232. [CrossRef]

79. Mellenthin, L.; Wallaschofski, H.; Grotevendt, A.; Völzke, H.; Nauck, M.; Hannemann, A. Association between serum vitamin D concentrations and inflammatory markers in the general adult population. Metabolism 2014, 63, 1056-1062. [CrossRef] [PubMed]

80. Florez, H.; Martinez, R.; Chacra, W.; Strickman-Stein, N.; Levis, S. Outdoor exercise reduces the risk of hypovitaminosis D in the obese. J. Steroid Biochem. Mol. Biol. 2007, 103, 679-681. [CrossRef] [PubMed]

81. Cheng, S.; Massaro, J.M.; Fox, C.S.; Larson, M.G.; Keyes, M.J.; McCabe, E.L.; Robins, S.J.; O’Donnell, C.J.; Hoffmann, U.; Jacques, P.F.; et al. Adiposity, cardiometabolic risk, and vitamin D status: The Framingham Heart Study. Diabetes 2010, 59, 242-248. [CrossRef] [PubMed]

82. Gangloff, A.; Bergeron, J.; Lemieux, I.; Després, J.P. Changes in circulating vitamin D levels with loss of adipose tissue. Curr. Opin. Clin. Nutr. Metab. Care. 2016, 19, 464-470. [CrossRef] [PubMed]

83. Larsen, S.C.; Ängquist, L.; Moldovan, M.; Huikari, V.; Sebert, S.; Cavadino, A.; Ahluwalia, T.S.; Skaaby, T.; Linneberg, A.; Husemoen, L.L.; et al. Serum 25-Hydroxyvitamin D Status and Longitudinal Changes in Weight and Waist Circumference: Influence of Genetic Predisposition to Adiposity. PLoS ONE 2016, 11, e0153611. [CrossRef] [PubMed]

84. LeBlanc, E.S.; Rizzo, J.H.; Pedula, K.L.; Ensrud, K.E.; Cauley, J.; Hochberg, M.; Hillier, T.A. Associations between 25hydroxyvitamin D and weight gain in elderly women. J. Womens Health 2012, 21, 1066-1073. [CrossRef]

85. Young, K.A.; Engelman, C.D.; Langefeld, C.D.; Hairston, K.G.; Haffner, S.M.; Bryer-Ash, M.; Norris, J.M. Association of plasma vitamin D levels with adiposity in Hispanic and African Americans. J. Clin. Endocrinol. Metab. 2009, 94, 3306-3313. [CrossRef]

86. Heitz, A.; Mai, X.M.; Chen, Y.; Sun, Y.Q. Serum 25-hydroxyvitamin D level in relation to weight change and the risk of weight gain in adults of normal weight at baseline: The Norwegian HUNT cohort study. BMJ Open 2020, 10, e039192. [CrossRef]

87. Berry, D.J.; Vimaleswaran, K.S.; Whittaker, J.C.; Hingorani, A.D.; Hyppönen, E. Evaluation of genetic markers as instruments for Mendelian randomization studies on vitamin D. PLoS ONE 2012, 7, e37465. [CrossRef]

88. Hüls, A.; Krämer, U.; Carlsten, C.; Schikowski, T.; Ickstadt, K.; Schwender, H. Comparison of weighting approaches for genetic risk scores in gene-environment interaction studies. BMC Genet. 2017, 18, 115. [CrossRef]

89. Babb de Villiers, C.; Kroese, M.; Moorthie, S. Understanding polygenic models, their development and the potential application of polygenic scores in healthcare. J. Med. Genet. 2020, 57, 725-732. [CrossRef]

90. Lewis, C.M.; Vassos, E. Polygenic risk scores: From research tools to clinical instruments. Genome Med. 2020, 12, 44. [CrossRef] 